\title{
Pengaruh Kualitas Sumber Daya Manusia, Pemanfaatan Teknologi Informasi, dan Sistem Pengendalian Intern terhadap Keandalan Pelaporan Keuangan pada Perusahaan Dealer Mobil di Sulawesi Utara
}

\author{
Oleh \\ Muhammad Saleh \\ Ventje Ilat
}

\begin{abstract}
ABSTRAK
Tujuan penelitian ini adalah untuk menganalisis dan memperoleh bukti empiris seberapa besar pengaruh kualitas sumber daya manusia, pemanfaatan teknologi informasi dan system pengendalian intern terhadap keandalan pelaporan keuangan perusahaan dealer mobil di Sulawesi Utara. Metode analisis yang digunakan dalam penelitian ini adalah metode analisis deskriptif kuantitatif, yaitu analisis yang menggunakan angka-angka dan perhitungan statistik untuk menganalisis suatu hipotesis dan memerlukan beberapa alat analisis

Hasil yang diperoleh adalah Kualitas Sumber Daya Manusia, Pemanfaatan Teknologi Informasi, dan Sistem Pengendalian Intern berpengaruh signifikan terhadap Keandalan Pelaporan Keuangan Perusahaan Dealer Mobil di Sulawesi Utara. Dengan demikian, variabel-variabel independen yang digunakan dalam model penelitian ini secara bersama-sama mampu menjelaskan variasi dari variabel dependen
\end{abstract}

Kata Kunci: Kualitas Sumber Daya Manusia, Pemanfaatan Teknologi Informasi, dan Sistem Pengendalian Intern, Pelaporan Keuangan.

\section{ABSTRAC}

The purpose of this study is to analyze and obtain empirical evidence of how much influence the quality of human resources, the utilization of information technology and internal control system to the reliability of financial reporting company car dealerships in North Sulawesi. The analytical method used in this research is descriptive quantitative analysis method, namely the analysis uses numbers and statistical calculations to analyze a hypothesis and requires some analysis tools.

The result is the Quality of Human Resources, Information Technology Utilization, and Internal Control System Reliability significant effect on the Company's financial reporting Car Dealers in North Sulawesi. Thus, the independent variables used in our model are jointly able to explain the variation of the dependent variable

Keywords : Quality of Human Resources, Information Technology Utilization, and Internal Control Systems, Financial Reporting . 


\section{PENDAHULUAN}

\subsection{Latar Belakang}

Sebuah informasi menjadi usang bila tidak lagi memberi manfaat bagi pengambilan keputusan. Ketepatan waktu penyusunan maupun pelaporan suatu laporan keuangan bisa berpengaruh terhadap nilai informasi laporan keuangan tersebut. Hal ini mencerminkan betapa pentingnya ketepatan waktu (timelines) penyajian laporan keuangan kepada publik. Perusahaan diharapkan tidak menunda penyajian laporan keuangannya yang dapat menyebabkan manfaat informasi yang disajikan menjadi berkurang. Semakin lama waktu tertunda dalam penyajian laporan keuangan suatu perusahaan ke publik, maka semakin banyak kemungkinan berkembangnya isu maupun kemungkinan terdapatnya insider information mengenai perusahaan tersebut. Semakin panjang waktu untuk publikasi laporan keuangan tahunan sejak akhir tahun buku suatu perusahaan, maka semakin besar kemungkinan informasi tersebut bocor kepada investor tertentu atau bahkan menimbulkan terjadinya masalah bagi perusahaan tersebut di bursa saham.

Selain itu, penyampaian laporan keuangan juga berhubungan dengan signaling theory dimana karena terdapatnya asimetri informasi antara manajer dan pemegang saham mengenai prospek perusahaan di masa mendatang (Yuliana dan Aloysia, 2004). Untuk meminimalisir hal tersebut perusahaan mengeluarkan sinyal-sinyal melalui penyampaian laporan keuangan. Penyampaian informasi melalui laporan keuangan oleh manajemen nantinya akan diterima oleh masyarakat sebagai suatu sinyal.

Tuntutan persaingan di berbagai bidang harus dijawab dengan perbaikan dan peningkatan kualitas SDM yang ada. Pola pengaturan dan pengawasan sumber daya manusia harus disesuaikan dengan kondisi yang ada. Steward dalam Polanyi (2000) menyebutkan bahwa sumber daya manusia adalah aktiva organisasi yang paling penting. Juga disebutkan oleh Polanyi (2000) bahwa sumber daya ini mempunyai sifat yang unik dan masalah pengukurannya pun komplek dan tidak mudah diidentifikasi ke pemiliknya, tetapi pengetahuan yang dimiliki sumber daya ini memiliki peranan yang besar dalam meningkatkan nilai dan kelangsungan hidup perusahaan. Jadi pengetahuan yang dimiliki karyawan akan menjadi aset yang berharga bagi perusahaan apabila diciptakan, dipelihara dan ditransformasikan dan dikelola sehingga mempunyai manfaat terhadap perusahaan, jika tidak maka pengetahuan tersebut tidak ada artinya.

Sumber daya manusia merupakan salah satu aset yang berpengaruh terhadap penyusunan laporan keuangan. Laporan keuangan merupakan sebuah produk yang dihasilkan oleh bidang atau disiplin ilmu akuntansi. Oleh karena itu, dibutuhkan Sumber Daya Manusia (SDM) yang kompeten untuk menghasilkan sebuah laporan keuangan yang berkualitas. Begitu juga di perusahaan yang bergerak pada usaha dealer mobil, untuk menghasilkan laporan keuangan yang berkualitas dibutuhkan SDM yang memahami dan kompeten dalam akuntansi keuangan.

Pesatnya kemajuan teknologi informasi serta potensi pemanfaatannyasecara luas dapat membuka peluang bagi berbagai pihak untuk mengakses, mengelola, dan mendayagunakan informasi keuangan secara cepat dan akurat. Manfaat lain yang ditawarkan dalam pemanfaatan teknologi informasi adalah kecepatan dalam pemrosesan informasi sehingga laporan keuangan dapat disajikan secara tepat waktu.

\section{TINJAUAN PUSTAKA \\ 2.1 Kajian Teoritis}

\subsubsection{Laporan Keuangan dan Pelaporan Keuangan}

Laporan keuangan mempunyai peranan penting karena laporan keuangan bertujuan untuk menyediakan informasi yang menyangkut posisi keuangan, kinerja, serta 
perubahan posisi keuangan suatu perusahaan yang bermanfaat bagi sejumlah besar pemakai dalam pengambilan keputusan ekonomi. Definisi laporan keuangan menurut Standar Akuntansi Keuangan yang dikeluarkan oleh Ikatan Akuntan Indonesia (2012) yaitu "Laporan keuangan bagian dari proses pelaporan keuangan. Laporan keuangan yang lengkap biasanya meliputi neraca, laporan laba-rugi, laporan perubahan posisi keuangan yang disajikan dalam berbagai cara (seperti misalnya sebagai laporan arus kas atau arus dana), catatan dan laporan lain serta materi penjelasan yang merupakan bagian integral dari laporan keuangan. Di samping itu juga termasuk skedul dan informasi tambahan yang berkaitan dengan laporan tersebut misalnya informasi keuangan segmen industri dan geografis serta pengungkapan pengaruh perubahan harga".

\subsubsection{Kualitas Sumber Daya Manusia}

Kualitas sumber daya manusia adalah kemampuan sumber daya manusia untuk melaksanakan tugas dan tanggung jawab yang diberikan kepadanya dengan bekal pendidikan, pelatihan, dan pengalaman yang cukup memadai (Widodo dalam Kharis, 2010). Wiley dalam Azhar (2007) mendefinisikan bahwa sumber daya manusia merupakan pilar penyangga utama sekaligus penggerak roda organisasi dalam usaha mewujudkan visi dan misi serta tujuan dari organisasi tersebut.

Sumber daya manusia merupakan salah satu elemen organisasi yang sangat penting, oleh karena itu harus dipastikan bahwa pengelolaan sumber daya manusia dilakukan sebaik mungkin agar mampu memberikan kontribusi secara optimal dalam upaya pencapaian tujuan organisasi. Dalam pengelolaan keuangan yang baik, perusahaan harus memiliki sumber daya manusia yang berkualitas, yang didukung dengan latar belakang pendidikan akuntansi, sering mengikuti pendidikan dan pelatihan, dan mempunyai pengalaman di bidang keuangan. Sehingga untuk menerapkan sistem akuntansi, sumber daya manusia (SDM) yang berkualitas tersebut akan mampu memahami logika akuntansi dengan baik.

\subsubsection{Teknologi Informasi}

Teknologi Informasi (TI) meliputi segala alat maupun metode yang terintegrasi untuk digunakan dalam menjaring atau menangkap data (capture), menyimpan (saving), mengolah (process), mengirim (distribute), atau menyajikan kebutuhan informasi secara elektronik ke dalam berbagai format, yang bermanfaat bagi user (pemakai informasi). Teknologi ini dapat berupa kombinasi perangkat keras dan lunak dari komputer, non komputer (manual) maupun prosedur, operator, dan para manajer dalam suatu sistem yang terpadu satu sama lain.

Perkembangan TI telah mengakibatkan perubahan dalam struktur industri serta praktik pengelolaan organisasi bisnis di dalam berkompetisi dan melaksanakan kegiatan untuk melayani pelanggan, sehingga dengan laju perkembangan TI yang semakin pesat telah mengubah bisnis dan konsep manajemen yang ada, juga berdampak terhadap kebutuhan informasi bagi manajer dalam akuntansi internal maupun eksternal guna mendukung dalam pemecahan masalah untuk pengambilan keputusan, meraih peluang dan mencapai tujuan. TI dipakai dalam sistem informasi organisasi untuk menyediakan informasi bagi para pemakai dalam rangka pengambilan keputusan.

\subsubsection{Pengertian Sistem Pengendalian Intern}

Pengendalian intern meliputi rencana organisasi dan semua metode dan ukuran serta kebijakan yang terkoordinasi dalam suatu perusahaan untuk mengamankan harta kekayaan, menjamin ketepatan, dan sampai seberapa jauh manajemen dapat dipercaya mendorong efisiensi operasional dan mendorong ditaatinya kebijakan pimpinan yang telah digariskan. Pengendalian intern menurut Committee on Auditing Procedures, SAS (Statement on Auditing Standars) Nomor 1 (par 320-09) 1984 - AICPA (American 
Institute of Certified Public Accountans) (Andayani, 2011) menyatakan pengendalian internal adalah "Internal control comprises the plan of organization an all of the coordinate methods and measures adopted within a bussiness to safeguard its assets, check the accuracy and relasbility of its accounting data, promote operational efficiency and encourage adherence to prescribed manajerial policies".

\subsubsection{Tujuan Pengendalian Intern}

Seperti yang dikemukakan oleh Mulyadi (2009:180) bahwa pengendalian intern merupakan suatu proses yang dijalankan oleh dewan komisaris, manajer dan personel lain yang didesain untuk memberikan keyakinan memadai tentang pencapaian tiga golongan yaitu (1) keandalan pelaporan keuangan, (2) kepatuhan terhadap hukum dan peraturan yang berlaku, (3) efektifitas dan efisiensi operasi. Dengan demikian pengendalian intern organisasi yang baik berarti untuk menilai (1) Keandalan Pelaporan Keuangan, (2) Efektifitas dan Efisiensi Operasi, (3) Kepatuhan terhadap hukum dan peraturan yang berlaku.

\section{METODE PENELITIAN}

Penelitian ini adalah penelitian kuantitatif yang menggunakan angka untuk menjelaskan hasil penelitian, dan biasanya menggunakan bantuan statistik untuk pengolahan data.

Penelitian dilaksanakan pada 14 perusahaan dealer mobil di Sulawesi Utara, yaitu: PT. Bosowa Berlian Motor (dealer Mitsubishi), PT. Hasjrat Abadi (dealer Toyota), PT. Gowa Dinasti Motor (dealer Hyundai), PT. Wahana Wirawan (dealer Nissan), PT. Sinar Galesong Prima (dealer Suzuki), PT. Kalla KIA Motor (dealer KIA), PT. Tujuh Dua-Dua (dealer Chevrolet), PT. Kumala Motor Prima (dealer Ford), PT. Nengga Pratama Internusa (dealer Hino), PT. Proton Edar Manado (dealer Proton), PT. Astra International Daihatsu (dealer Daihatsu), UD. Remaja Jaya (dealer Honda), PT. Isuzu Astra Internasional (dealer Isuzu), dan CV. Dwi Sejati (dealer Cherry). Penelitian telah dilaksanakan selama bulan September sampai dengan bulan November 2012.

Metode analisis yang digunakan dalam penelitian ini adalah metode analisis deskriptif kuantitatif, yaitu analisis yang menggunakan angka-angka dan perhitungan statistik untuk menganalisis suatu hipotesis dan memerlukanbeberapa alat analisis.

Alat analisa yang dipakai untuk mengetahui pengaruh variabel kualitas sumber daya manusia, pemanfaatan teknologi informasi, dan sistem pengendalian intern terhadap keandalan pelaporan keuangan adalah analisa regresi berganda (multiple regression analysis). Analisa regresi pada dasarnya adalah studi ketergantungan variabel dependen (terikat) dengan satu atau lebih variabel independen (variabel penjelas/bebas), dengan tujuan untuk mengestimasi dan/atau memprediksi rata-rata populasi atau nilai rata-rata variabel dependen berdasarkan nilai variabel independen yang diketahui.

\section{HASIL PENELITIAN DAN PEMBAHASAN}

\subsubsection{Deskripsi Umum Responden Penelitian}

Penelitian ini dilakukan pada 70 karyawan perusahaan dealer mobil di Sulawesi Utara. Tabel 4.1 menyajikan gambaran umum responden yang menjadi sampel dalam penelitian ini.

Tabel 4.1 Komposisi Responden
Berdasarkan Jenis Kelamin
\begin{tabular}{|l|c|c|}
\hline Jenis Kelamin & Jumlah & Prosentase \\
\hline Laki-laki & 38 & $54 \%$ \\
\hline Perempuan & 32 & $46 \%$ \\
\hline
\end{tabular}




\begin{tabular}{|l|c|c|}
\hline Total & 70 & $100 \%$ \\
\hline
\end{tabular}

Sumber: Data Olahan (2013)

Dari table 4.1 dapat dilihat bahwa jenis kelamin responden terdiri dari laki-laki sebanyak 38 orang dengan nilai prosentase sebesar $54 \%$ dan wanita sebanyak 32 orang dengan nilai prosentase sebesar $46 \%$.

Adapun komposisi responden berdasarkan pendidikan terakhir dapat dilihat pada table 4.2 berikut ini.

\section{Tabel 4.2 Komposisi Responden Berdasarkan Pendidikan Terakhir}

\begin{tabular}{|c|c|c|}
\hline Tingkat Pendidikan & Jumlah & Prosentase \\
\hline SMU & 2 & $3 \%$ \\
\hline Diploma & 13 & $19 \%$ \\
\hline S1 & 50 & $71 \%$ \\
\hline S2 & 5 & $7 \%$ \\
\hline S3 & - & - \\
\hline Total & 70 & $100 \%$ \\
\hline
\end{tabular}

Sumber: Data Olahan (2013)

Dari Tabel 4.2 dapat dilihat bahwa sebagian besar responden memiliki tingkat pendidikan terakhir sarjana (S1) sebanyak 50 orang dengan nilai prosentase sebesar $71 \%$, kemudian diploma sebanyak 13 orang dengan nilai prosentase sebesar $19 \%$, lalu tingkat pendidikan terakhir magister (S2) sebanyak 5 orang dengan nilai prosentase sebesar 7\% dan yang paling sedikit adalah tingkat pendidikan SMU sebanyak 2 orang dengan nilai prosentase sebesar 3\%. Menurut latar belakang pendidikan, komposisi responden penelitian ini adalah sebagai berikut.

Tabel 4.3 Komposisi Responden Berdasarkan LatarBelakang Pendidikan

\begin{tabular}{|c|c|c|}
\hline Bidang & Jumlah & Prosentase \\
\hline Ekonomi & 59 & $84 \%$ \\
\hline Hukum & 6 & $9 \%$ \\
\hline Teknik & 2 & $3 \%$ \\
\hline Lainnya & 3 & $4 \%$ \\
\hline Total & 70 & $100 \%$ \\
\hline
\end{tabular}

Sumber: Data Olahan (2013)

Tabel 4.3 menunjukkan bahwa jumlah responden berdasarkan latar belakang pendidikan ekonomi sebanyak 59 orang dengan persentase $84 \%$, pendidikan hukum sebanyak 6 orang dengan persentase $9 \%$, berlatar belakang pendidikan teknik sebanyak 2orang dengan persentase $3 \%$ dan lainnya sebanyak 3 orang dengan persentase $4 \%$.

Berdasarkan waktu/lamanya bekerja, komposisi responden penelitian adalah sebagai berikut:

Tabel 4.4 Komposisi Responden Berdasarkan Lama Bekerja

\begin{tabular}{|c|c|c|}
\hline Usia (tahun) & Jumlah & Prosentase \\
\hline$<1$ tahun & 12 & $17 \%$ \\
\hline $1-2$ tahun & 24 & $34 \%$ \\
\hline$>2$ tahun & 34 & $49 \%$ \\
\hline Total & 70 & $100 \%$ \\
\hline
\end{tabular}

Sumber: Data olahan (2013)

Dari tabel 4.4 dapat dilihat bahwa jumlah responden yang bekerja kurang dari 1 tahun adalah 12 orang dengan prosentase $17 \%$, responden yang bekerja antara 1-2 tahun berjumlah 24 orang dengan prosentase $34 \%$, sedangkan responden yang bekerja di atas 2 tahun berjumlah 34 orang dengan prosentase $49 \%$. Dengan demikian, sebagian 
besar responden telah bekerja dalam rentang waktu yang cukup lama sehingga diasumsikan bahwa seluruh responden penelitian ini telah menguasai bidang tugas masing-masing.

Berdasarkan tingkat usia, komposisi responden penelitian adalah sebagai berikut:

Tabel 4.5 Komposisi Responden Berdasarkan Usia

\begin{tabular}{|c|c|c|}
\hline Usia (tahun) & Jumlah & Prosentase \\
\hline $21-30$ & 39 & $56 \%$ \\
\hline $31-40$ & 18 & $26 \%$ \\
\hline$>40$ & 13 & $19 \%$ \\
\hline Total & 70 & $100 \%$ \\
\hline
\end{tabular}

Sumber: Data olahan (2013)

Dari tabel 4.5 dapat dilihat bahwa jumlah responden yang berusia antara 21-30 tahun adalah 39 orang dengan prosentase 56\%, usia 31-40 tahun berjumlah 18 orang dengan prosentase $26 \%$, dan responden yang berusia diatas 13 tahun berjumlah 4 orang dengan prosentase $19 \%$.

Kuesioner telah disebarkan kepada 70 responden penelitian yang tersebar pada 14 perusahaan dealer mobil di Sulawesi Utara. Kuesioner telah diisi lengkap kemudian dikembalikan pada peneliti sebanyak 70 kuesioner. Dengan demikian, semua kuesioner dikembalikan oleh responden sesuai dengan hasil pengamatan (observasi) yang dilakukan pada obyek penelitian, yaitu 14 perusahaan dealer mobil di Sulawesi Utara. Hasil yang diperoleh selanjutnya ditabulasi menggunakan bantuan Microsoft Excel dengan tingkatan score berbasis skala Likert. Adapun hasil tabulasi data dapat dilihat pada lampiran 2 .

\subsubsection{Uji Validitas dan Reliabilitas}

Untuk mengetahui apakah jawaban yang diberikan responden dapat dipercaya atau dapat diandalkan maka digunakan analisis reliabilitas melalui metode cronbach alpha, dimana suatu instrumen dikatakan reliabel bila memiliki koefisen keandalan (alpha) sebesar 0,6 atau lebih.

\subsubsection{Uji Asumsi Klasik}

\subsubsection{Uji Heteroskesdastisitas}

Berdasarkan hasil software Program SPSS Version 19.0, dapat dilihat hasil scatterplot parsial $\mathrm{X}_{1}, \mathrm{X}_{2}$, dan $\mathrm{X}_{3}$ terhadap variabel $\mathrm{Y}$ tidak ada pola yang terbentuk, dengan kata lain grafik menggambarkan plot menyebar, yaitu bebas heteroskesdastisitas.

\subsubsection{Uji Multikolinieritas}

Uji multikolinieritas bertujuan untuk mengetahui apakah di dalam model regresi terdapat korelasi antar variabel independen.

Tabel 4.10 UjiMultikolinearitas

\begin{tabular}{|c|c|c|c|}
\hline \multicolumn{4}{|c|}{ Coefficients $^{a}$} \\
\hline \multirow[b]{2}{*}{ Model } & & \multicolumn{2}{|c|}{$\begin{array}{l}\text { Collinearity } \\
\text { Statistics }\end{array}$} \\
\hline & & Tolerance & VIF \\
\hline \multirow[t]{4}{*}{1} & (Constant) & & \\
\hline & $\begin{array}{l}\text { Kualitas Sumber Daya } \\
\text { Manusia }\end{array}$ & .482 & 2.077 \\
\hline & $\begin{array}{l}\text { Pemanfaatan Teknologi } \\
\text { Informasi }\end{array}$ & .378 & 2.646 \\
\hline & Sistem Pengendalian & .505 & 1.982 \\
\hline
\end{tabular}




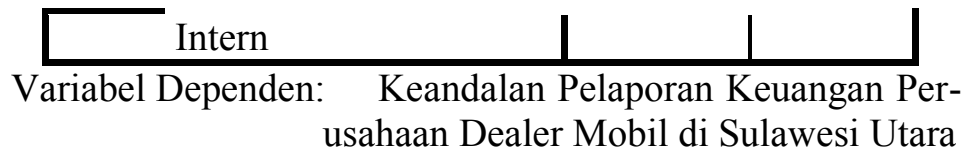

Sumber :Data hasil olahan (2013)

Hasil analisis pada tabel 4.10 menunjukkan bahwa nilai VIF semua variabel independen berada di bawah 5 dan nilai tolerance berada di atas 0,10 , sehingga dapat disimpulkan bahwa tidak terjadi multikolinieritas.

\subsubsection{Uji Normalitas}

Gambar 4.5 menunjukkan bahwa grafik normal $P$-P of regression standardized residual menggambarkan penyebaran data di sekitar garis diagonal dan penyebarannya mengikuti arah garis diagonal grafik tersebut. Dengan demikian, model regresi yang digunakan dalam penelitian ini memenuhi asumsi normalitas.

\section{Gambar 4.5 Uji Normalitas}

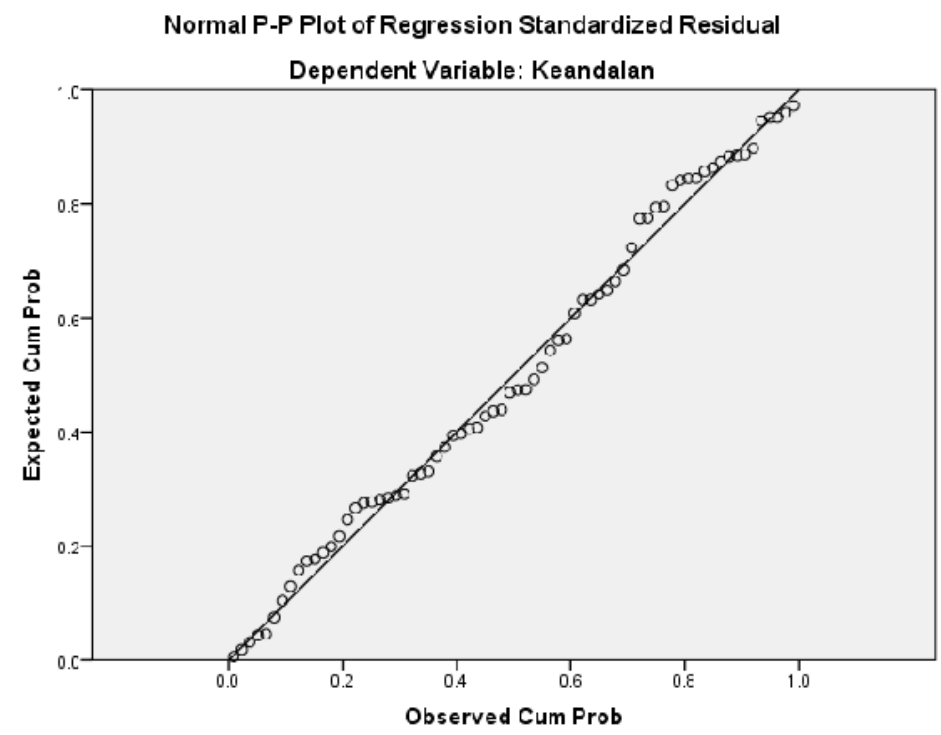

Sumber: Data hasil olahan (2013)

\subsubsection{Analisis Regresi Linear Berganda}

Pada tabel 4.11, dapat diketahui koefisien untuk persamaan regresi dari data yang diteliti.

Tabel 4.11 Koefisien Persamaan Coefficients $^{\mathrm{a}}$

\begin{tabular}{|c|c|c|c|}
\hline \multirow{2}{*}{\multicolumn{2}{|c|}{ Model }} & \multicolumn{2}{|c|}{$\begin{array}{c}\text { Unstandardized } \\
\text { Coefficients }\end{array}$} \\
\hline & & $\mathrm{B}$ & Std. Error \\
\hline \multirow[t]{4}{*}{1} & (Constant) & 17.889 & 3.047 \\
\hline & $\begin{array}{l}\text { Kualitas Sumber Daya } \\
\text { Manusia }\end{array}$ & .108 & .137 \\
\hline & $\begin{array}{l}\text { Pemanfaatan Teknolog } \\
\text { Informasi }\end{array}$ & .128 & .130 \\
\hline & $\begin{array}{l}\text { Sistem Pengendalian } \\
\text { Intern }\end{array}$ & .202 & .119 \\
\hline
\end{tabular}

Sumber: Data hasil olahan (2012) 
Dari hasil perhitungan untuk analisa kuantitatif berdasarkan metode analisis regresi linear berganda (multiple regression) diperoleh persamaan sebagai berikut:

$$
Y_{1}=17,889+0,108 X_{1}+0,128 X_{2}+0,202 X_{3}
$$

Hasil regresi ini menunjukkan pengaruh variabel bebas (kualitas sumber daya manusia, pemanfaatan teknologi informasi dan sistem pengendalian intern) terhadap variabel terikat (keandalan pelaporan keuangan perusahaan dealer mobil).

Nilai konstan sebesar 17,889 menunjukkan bahwa jika variabel kualitas sumber daya manusia, pemanfaatan teknologi informasi dan sistem pengendalian intern dianggap konstan atau sama dengan nol (0) maka tingkat keandalan pelaporan keuangan perusahaan dealer mobil di Sulawesi Utara adalah 17,889 satuan skor.

Koefisien regresi $\mathrm{X}_{1}$ sebesar 0,108 mengartikan bahwa jika faktor kualitas sumber daya manusia meningkat sebesar 1 satuan skor dari kondisi sebelumnya, maka tingkat keandalan pelaporan keuangan perusahaan dealer mobil akan meningkat sebesar 0,108 satuan skor dari kondisi sebelumnya dengan asumsi variabel lain $\left(\mathrm{X}_{2}\right.$ dan $\left.\mathrm{X}_{3}\right)$ yang diteliti tetap.

Koefisien regresi $\mathrm{X}_{2}$ sebesar 0,128 mengartikan bahwa jika faktor pemanfaatan teknologi informasi meningkat sebesar 1 satuan skor dari kondisi sebelumnya, maka tingkat keandalan pelaporan keuangan perusahaan dealer mobil akan meningkat sebesar 0,128 satuan skor dari kondisi sebelumnya dengan asumsi variabel lain $\left(\mathrm{X}_{1}\right.$ dan $\left.\mathrm{X}_{3}\right)$ yang diteliti tetap.

Koefisien regresi $\mathrm{X}_{3}$ sebesar 0,202mengartikan bahwa jika faktor sistem pengendalian intern meningkat sebesar 1 satuan skor dari kondisi sebelumnya, maka tingkat keandalan pelaporan keuangan perusahaan dealer mobil akan meningkat sebesar 0,202 satuan skor dari kondisi sebelumnya dengan asumsi variabel lain $\left(\mathrm{X}_{1}\right.$ dan $\left.\mathrm{X}_{2}\right)$ yang diteliti tetap.

\subsubsection{Koefisien Korelasi (R) dan Koefisien Determinasi $\left(\mathbf{R}^{2}\right)$}

Hasil pengolahan data dengan program software SPSS 19.0 menunjukkan nilai koefisien korelasi dan koefisien determinasi secara simultan seperti yang dapat dilihat pada tabel 4.12.

Berdasarkan hasil perhitungan pada tabel 4.12, dapat dilihat bahwa koefisien korelasi linear yang dihasilkan antara kualitas sumber daya manusia $\left(\mathrm{X}_{1}\right)$ dengan keandalan pelaporan keuangan (Y) perusahaan dealer mobil adalah 0,394 dan bersifat positif. Hal ini berarti terdapat hubungan antara variabel $\mathrm{X}_{1}$ dengan variabel $\mathrm{Y}$ meskipun tingkat hubungannya tidak begitu kuat sebab koefisien korelasinya $<0,5$. Koefisien korelasi linear yang dihasilkan antara pemanfaatan teknologi informasi $\left(\mathrm{X}_{2}\right)$ dengan keandalan pelaporan keuangan (Y) adalah sebesar 0,437 dan bersifat positif. $\mathrm{Hal}$ ini berarti terdapat hubungan antara variabel $\mathrm{X}_{2}$ dengan variabel $\mathrm{Y}_{1}$ meskipun tingkat hubungannya tidak begitu kuat sebab koefisien korelasinya $<0,5$. Koefisien korelasi linear yang dihasilkan antara sistem pengendalian intern dengan keandalan pelaporan keuangan (Y) adalah sebesar 0,447 dan bersifat positif hal ini berarti terdapat hubungan antara variabel $\mathrm{X}_{3}$ dengan variabel $\mathrm{Y}$ meskipun tingkat hubungannya tidak begitu kuat sebab koefisien korelasinya $<0,5$.

Tabel 4.12 Koefisien Korelasi

Correlations

\begin{tabular}{|l|r|}
\hline & Keandalan \\
\hline Pearson Correlation Keandalan & 1.000 \\
Kualitas Sumber Daya Manusia & .394 \\
Pemanfaatan Teknologi Informasi & .437 \\
Sistem Pengendalian Intern & .447 \\
\hline
\end{tabular}




\begin{tabular}{|ll|r|}
\hline Sig. (1-tailed) & Keandalan & \\
& Kualitas Sumber Daya Manusia & .000 \\
& Pemanfaatan Teknologi Informasi & .000 \\
& Sistem Pengendalian Intern & .000 \\
\hline $\mathrm{N}$ & Keandalan & 70 \\
& Kualitas Sumber Daya Manusia & 70 \\
& Pemanfaatan Teknologi Informasi & 70 \\
& Sistem Pengendalian Intern & 70 \\
\hline
\end{tabular}

Sumber: Data Hasil Olahan (2013)

Tabel4.13 Koefisien Determinasi Variabel Kualitas Sumber Daya Manusia, Pemanfaatan Teknologi Informasi, dan Sistem Pengendalian Intern terhadap Keandalan Pelaporan Keuangan

\begin{tabular}{|l|c|r|r|r|}
\hline \multicolumn{5}{|c|}{ Model Summary $^{\mathbf{b}}$} \\
\hline Model & R & R Square & $\begin{array}{c}\text { Adjusted R } \\
\text { Square }\end{array}$ & $\begin{array}{c}\text { Std. Error of } \\
\text { the Estimate }\end{array}$ \\
\hline 1 & $.488^{\mathrm{a}}$ & .238 & .204 & 2.085 \\
\hline
\end{tabular}

Sumber: Data hasil olahan (2013)

Dari tabel 4.13 dapat diketahui nilai adjusted $R$ square yang diperoleh adalah sebesar 0,204 atau 20,4\% artinya variabel Kualitas Sumber Daya Manusia, Pemanfaatan Teknologi Informasi, dan Sistem Pengendalian Internberpengaruh sebesar 20,4\% terhadap Keandalan Pelaporan Keuangan Perusahaan Dealer Mobil di Sulawesi Utara, sedangkan sisanya sebesar 79,6\% dijelaskan oleh faktor lain diluar penelitian ini.

\subsubsection{Pengujian Hipotesis}

\subsubsection{Uji F}

Tabel 4.14 menunjukkan hasil uji F guna menguji semua variabel bebas (kualitas sumber daya manusia, pemanfaatan teknologi informasi, dan sistem pengendalian intern) yang mempengaruhi variabel Y (keandalan pelaporan keuangan perusahaan dealer mobil).

Tabel 4.14 ANOVA ${ }^{\text {b }}$ Keandalan Pelaporan Keuangan Perusahaan Dealer Mobil di Sulawesi Utara

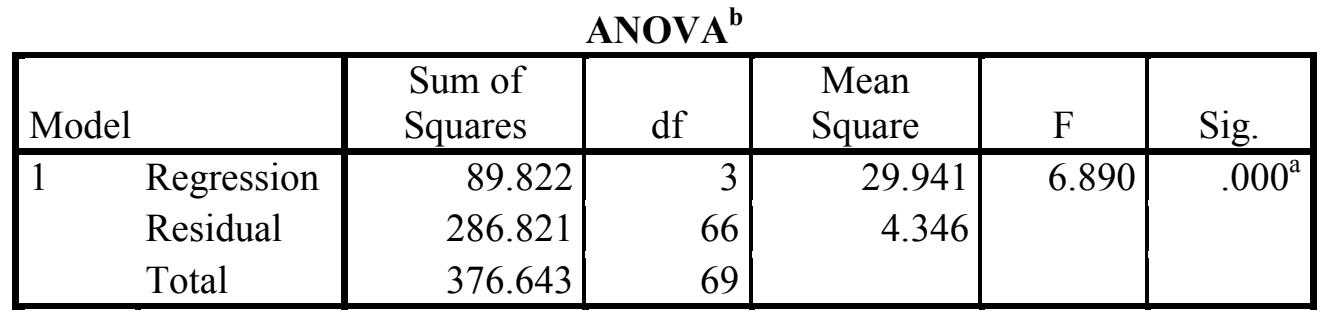

a. Predictors: (Constant), Sistem Pengendalian Intern, Kualitas Sumber Daya

Manusia, Pemanfaatan Teknologi Informasi

b. Dependent Variable: Keandalan Pelaporan Keuangan

Sumber: Data Hasil Olahan (2013)

Dari tabel Anova didapat nilai $\mathrm{F}_{\text {hitung }}=6,890$ dengan menggunakan derajat keyakinan $95 \%$ atau taraf nyata $5 \%$ serta derajat kebebasan dari $\mathrm{df}_{1}=3 \mathrm{dan} \mathrm{df}_{2}=66$ didapat nilai $\mathrm{F}_{\text {tabel }}=2,75$. Jadi, nilai $\mathrm{F}_{\text {hitung }}<\mathrm{F}_{\text {tabel }}$, sehingga $\mathrm{H}_{0}$ diterima dan $\mathrm{H}_{\mathrm{a}}$ ditolak.

Dengan demikian, hasil uji $\mathrm{F}$ menyatakan bahwavariabel bebas (kualitas sumber daya manusia, pemanfaatan teknologi informasi, dan sistem pengendalian 
intern) secara bersama-sama (simultan) berpengaruh secara signifikan terhadap variabel tergantung (keandalan pelaporan keuangan) perusahaan dealer mobil.

\subsubsection{Uji t}

Untuk mengetahui pengaruh secara parsial dari masing-masing variabel independen (kualitas sumber daya manusia, pemanfaatan teknologi informasi, dan sistem pengendalian intern) terhadap variabel dependen (Y) keandalan pelaporan keuangan perusahaan dealer mobil digunakan konsep uji-t, dengan prosedur analisis sebagai berikut :

\section{Tabel 4.15 Uji Signifikansi Kualitas Sumber Daya Manusia} Coefficients $^{\mathrm{a}}$

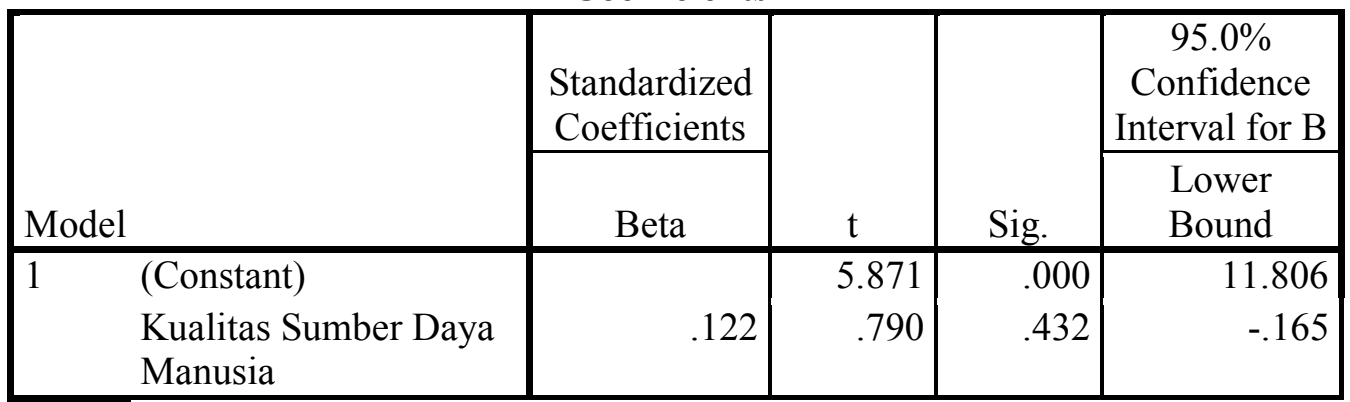

Sumber: Data hasil olahan (2013)

Pada tabel 4.15 dapat diketahui hasil uji-t untuk variabel Kualitas Sumber Daya Manusia $\left(\mathrm{X}_{1}\right)$ memperoleh nilai $\mathrm{t}_{\text {hitung }}$ variabel $\mathrm{X}_{1}$ sebesar 0,790 sehingga dengan tingkat kepercayaan $5 \%$ pada derajat kebebasan $(\mathrm{N}-2)=70-2=68$, dapat diketahui nilai $t_{\text {tabel }}$ sebesar 2,000 . Dengan demikian nilai $t_{\text {hitung }}<t_{\text {tabel }}$, artinya variabel kualitas sumber daya manusia $\left(\mathrm{X}_{1}\right)$ tidak berpengaruh secara signifikan terhadap keandalan pelaporan keuangan (variabel Y) perusahaan dealer mobil.

Tabel 4.16 Uji Signifikansi Pemanfaatan Teknologi Informasi Coefficients $^{\mathbf{a}}$

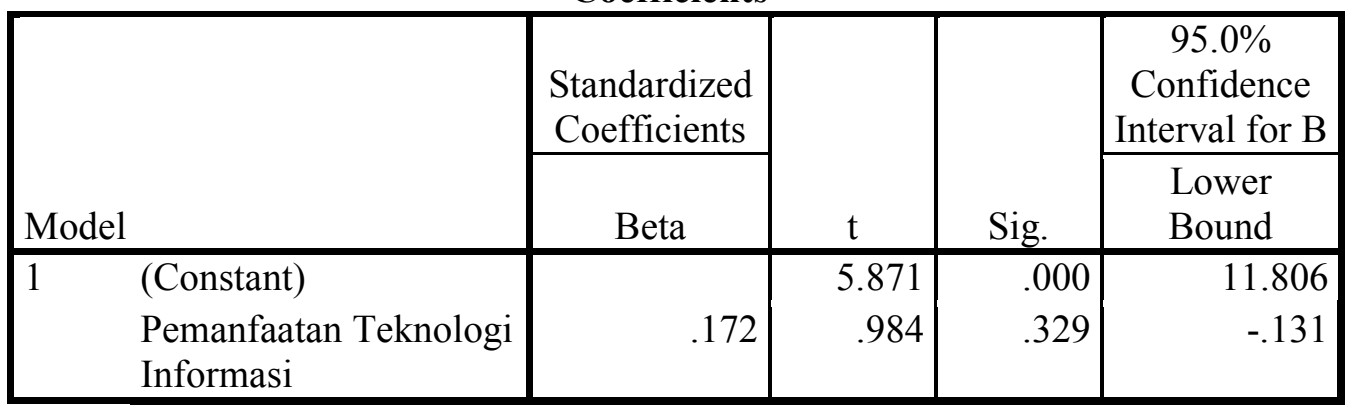

Sumber: Data hasil olahan (2013)

Tabel 4.16 menunjukkan hasil uji-t variabel Pemanfaatan Teknologi Informasi $\left(\mathrm{X}_{2}\right)$ bahwa nilai $\mathrm{t}_{\text {hitung }}$ adalah 0,984 dengan tingkat kepercayaan $5 \%$ pada derajat kebebasan $(\mathrm{N}-2)=70-2=68$, dapat diketahui nilai $\mathrm{t}_{\text {tabel }}$ sebesar 2,000. Dengan demikian nilai $t_{\text {hitung }}<t_{\text {tabel }}$, artinya variabel pemanfaatan teknologi informasi $\left(\mathrm{X}_{2}\right)$ tidak berpengaruh signifikan terhadap keandalan pelaporan keuangan (variabel $Y$ ) perusahaan dealer mobil.

Tabel 4.17 Uji Signifikansi Sistem Pengendalian Intern Coefficients $^{\mathrm{a}}$

\begin{tabular}{|l|l|l|l|c|}
\hline & $\begin{array}{c}\text { Standardized } \\
\text { Coefficients }\end{array}$ & $\mathrm{t}$ & Sig. & $\begin{array}{c}95.0 \% \\
\text { Confidence } \\
\text { Interval for B B }\end{array}$ \\
\hline
\end{tabular}




\begin{tabular}{|ll|r|r|r|r|}
\hline & \multicolumn{1}{|c|}{ Beta } & & & \multicolumn{1}{c|}{$\begin{array}{c}\text { Lower } \\
\text { Bound }\end{array}$} \\
\hline $1 \quad$ (Constant) & & 5.871 & .000 & 11.806 \\
& Sistem Pengendalian & .257 & 1.702 & .093 & -.035 \\
& Intern & & & & \\
\hline
\end{tabular}

Sumber: Data hasil olahan (2013)

Pada tabel 4.17 hasil uji-t variabel Sistem Pengendalian Intern $\left(\mathrm{X}_{2}\right)$ memperoleh nilai $t_{\text {hitung }}=1,702$ dengan tingkat kepercayaan $5 \%$ pada derajat kebe-basan $(\mathrm{N}-2)=70-2=68$, dapat diketahui nilai $t_{\text {tabel }}$ sebesar 2,000. Dengan demikian, nilai $t_{\text {hitung }}<t_{\text {tabel }}$ artinya variabel sistem pengendalian intern $\left(X_{3}\right)$ tidak berpengaruh signifikan terhadap keandalan pelaporan keuangan perusahaan dealer mobil (Y).

4.1 Evaluasi

4.2.1. Kualitas Sumber Daya Manusia tidak Berpengaruh Signifikan terhadap Keandalan Pelaporan Keuangan Perusahaan Dealer Mobil di Sulawesi Utara

Hasil analisis data dan pengujian hipotesis memperlihatkan bahwa kualitas sumber daya manusia tidak berpengaruh signifikan terhadap keandalan pelaporan keuangan perusahaan dealer mobil di Sulawesi Utara. Fakta yang ditemukan di lapangan mengindikasikan bahwa sebagian besar rekrutmen staf akuntansi masih berasal dari lulusan perguruan tinggi yang berlatarbelakang pendidikan di luar bidang ilmu akuntansi. Padahal fungsi dan proses akuntansi hanya dapat dilaksanakan oleh staf yang memiliki pengetahuan di bidang ilmu akuntansi. Selain itu, uraian tugas dan fungsi (job description) staf akuntansi yang ada masih terlalu umum (belum terspesifikasi dengan jelas).

Faktor lain yang memicu lemahnya pengaruh kualitas sumber daya manusia terhadap keandalan pelaporan keuangan perusahaan dealer mobil di Sulawesi Utara adalah masih rendahnya frekuensi pendidikan dan pelatihan penyusunan laporan keuangan yang disesuaikan dengan perkembangan terbaru Standar Akuntansi Keuangan (SAK). Oleh karena itu, hasil penelitian ini mendukung studi empirik yang dilakukan oleh Indriasari (2008).

\subsubsection{Pemanfaatan Teknologi Informasi tidak Berpengaruh Signifikan terhadap Keandalan Pelaporan Keuangan Perusahaan Dealer Mobil di Sulawesi Utara}

Hasil analisis data dan pengujian hipotesis memperlihatkan bahwa pemanfaatan teknologi informasi tidak berpengaruh signifikan terhadap keandalan pelaporan keuangan perusahaan dealer mobil di Sulawesi Utara. Realita ini dipicu oleh masih rendahnya kesadaran manajemen dealer mobil di Sulawesi Utara dalam memperbaharui (up-grade) aplikasi teknologi informasi (software) sesuai revisi terbaru Standar Akuntansi Keuangan (SAK).Selain itu, masih ada transaksi yang belum terkomputerisasi sehingga mengurangi keandalan pelaporan keuangan perusahaan dealer mobil di Sulawesi Utara.

4.2.3. Sistem Pengendalian Intern tidak Berpengaruh Signifikan terhadap Keandalan Pelaporan Keuangan Perusahaan Dealer Mobil di Sulawesi Utara

Hasil analisis data dan pengujian hipotesis menunjukkan bahwa sistem pengendalian intern berpengaruh tidak signifikan terhadap keandalan pelaporan keuangan perusahaan dealer mobil di Sulawesi Utara. Faktor penyebab anomali ini adalah lemahnya sistem pengendalian intern terkait dengan proses penyusunan laporan 
keuangan sehingga mengurangi tingkat keandalan pelaporan keuangan perusahaan dealer mobil di Sulawesi Utara.

\subsubsection{Kualitas Sumber Daya Manusia, Pemanfaatan Teknologi Informasi, dan Sistem Pengendalian Intern berpengaruh signifikan terhadap Keandalan Pelaporan Keuangan Perusahaan Dealer Mobil di Sulawesi Utara}

Hasil analisis data dan pengujian hipotesis memperlihatkan bahwa kualitas sumber daya manusia, pemanfaatan teknologi informasi, dan sistem pengendalian intern berpengaruh signifikan terhadap keandalan pelaporan keuangan perusahaan dealer mobil di Sulawesi Utara.Dengan demikian, variabel-variabel independen yang digunakan dalam model penelitian ini secara bersama-sama mampu menjelaskan variasi dari variabel dependen. Hasil penelitian ini mendukung studi empirik yang dilakukan oleh Indriasari (2008).

\section{PENUTUP}

\subsection{Kesimpulan}

Berdasarkan analisis hasil penelitian dan pembahasan yang telah dilakukan sebelumnya, maka dapat ditarik kesimpulan sebagai berikut:

1. Kualitas Sumber Daya Manusia tidak berpengaruh signifikan terhadap Keandalan Pelaporan Keuangan Perusahaan Dealer Mobil di Sulawesi Utara. Faktor penyebabnya adalah rekrutmen staf akuntansi yang berlatarbelakang pendidikan di luar bidang ilmu akuntansi dan belum jelasnya uraian tugas dan fungsi (job description) staf akuntansi yang ada, serta masih rendahnya frekuensi pendidikan dan pelatihan penyusunan laporan keuangan yang disesuaikan dengan perkembangan terbaru Standar Akuntansi Keuangan (SAK). Oleh karena itu, hasil penelitian ini mendukung studi empirik yang dilakukan oleh Indriasari (2008).

2. Sistem Pengendalian Intern tidak berpengaruh signifikan terhadap Keandalan Pelaporan Keuangan Perusahaan Dealer Mobil di Sulawesi Utara. Faktor penyebabnya adalah lemahnya Sistem Pengendalian Intern terkait dengan proses penyusunan laporan keuangan sehingga mengurangi tingkat Keandalan Pelaporan Keuangan Perusahaan Dealer Mobil di Sulawesi Utara.

3. Pemanfaatan Teknologi Informasi tidak berpengaruh signifikan terhadap Keandalan Pelaporan Keuangan Perusahaan Dealer Mobil di Sulawesi Utara. Pemicunya yaitu rendahnya kesadaran manajemen dealer mobil di Sulawesi Utara dalam memperbaharui (up-grade) aplikasi teknologi informasi (software) sesuai revisi terbaru Standar Akuntansi Keuangan (SAK) serta masih ada transaksi yang belum terkomputerisasi sehingga mengurangi Keandalan Pelaporan Keuangan Perusahaan Dealer Mobil di Sulawesi Utara.

4. Kualitas Sumber Daya Manusia, Pemanfaatan Teknologi Informasi, dan Sistem Pengendalian Intern berpengaruh signifikan terhadap Keandalan Pelaporan Keuangan Perusahaan Dealer Mobil di Sulawesi Utara. Dengan demikian, variabelvariabel independen yang digunakan dalam model penelitian ini secara bersamasama mampu menjelaskan variasi dari variabel dependen.

\subsection{Saran}

Berdasarkan kesimpulan yang telah diuraikan sebelumnya, maka penulis merekomendasikan beberapa hal sebagai berikut:

1. Manajemen Perusahaan Dealer Mobil di Sulawesi Utara seharusnya meningkatkan frekuensi pelaksanaan kegiatan pendidikan dan pelatihan (diklat) bagi karyawan guna meningkatkan kualitas sumber daya manusia guna meningkatkan tingkat keandalan pelaporan keuangannya. 
2. Manajemen Perusahaan Dealer Mobil di Sulawesi Utara hendaknya mengupayakan pembaharuan (upgrade) Teknologi Informasi dalam penyusunan laporan keuangan agar informasi yang tersedia dapat lebih dapat diandalkan oleh para pemangku kepentingan (stakeholders).

3. Manajemen Perusahaan Dealer Mobil di Sulawesi Utara seyogyanya menerapkan akselerasi atas implementasi Sistem Pengendalian Intern pada tiap perusahaan guna mencapai peningkatan keandalan pelaporan keuangan.

\section{DAFTAR PUSTAKA}

Agoes, Sukrisno. 2004. Auditing (Pemeriksaan Akuntan) oleh Kantor Akuntan Publik. Edisi Ketiga. Penerbit Fakultas Ekonomi Universitas Trisakti.

Baridwan, Zaki. 2004. Intermediate Accounting Ed.ke-8. Yogyakarta: BPFE.

Brigham, E.F. dan J.F. Weston. 2005. Dasar-dasar Manajemen Keuangan. Edisi Kesembilan. Jilid 2. Jakarta: Penerbit Erlangga.

Ghozali, Imam dan Anis Chariri. 2007. Teori Akuntansi EdisiKetiga. Semarang: Badan Penerbit Universitas Diponegoro.

Hanafi, Mamduh M. 2004. Manajemen Keuangan. Yogyakarta: BPFE.

Hendriksen, Eldon S. 2000. Teori Akuntansi. Edisi Kelima. Editor: Lindon Saputra. Alih Bahasa: Herman Wibowo. Jakarta: Interaksara.

Ikatan Akuntan Indonesia. 2012. Standar Akuntansi Keuangan. Jakarta: Salemba Empat.

Mahmudi. 2007. Manajemen Kinerja Sektor Publik. Yogyakarta: Unit Penerbit dan Percetakan Sekolah Tinggi Ilmu Manajemen YKPN.

Masyhuri, Zainuddin, M. Metodologi Penelitian Pendekatan Praktis dan Aplikatif. Cetakan kedua. Penerbit PT. Refika Aditama Bandung, 2009.

Polanyi, Michael. 2000. Segi Tak Terungkap Ilmu Pengetahuan. Jakarta: Gramedia Pustaka Utama.

Rahardja, Prathama. 2001. Uang dan Perbankan. Jakarta: PT. Gramedia Pustaka Utama.

Suwardjono. 2005. Teori Akuntansi Perekayasaan Pelaporan Keuangan Edisi Ketiga. Yogyakarta: BPFE.

Wilkinson, Josep W. et.al. 2000. Accounting Information System Essential Concept and Application. 4th Edition. New York-USA: John Willey \& Sons Inc. 